\title{
Pelatihan Penggunaan Alat Peraga Matematika bagi Guru SD GMIT Koro'oto, Kupang, Nusa Tenggara Timur
}

\author{
Kristoforus Djawa Djong, Yohanes Ovaritus Jagom, Samuel Igo Leton, Yohana Rina Rowa, \\ Irmina Veronika Uskono, Wilfridus Beda Nuba Dosinaeng, Meryani Lakapu \\ Departemen Pendidikan, Fakultas Keguruan dan Ilmu Pendidikan, Universitas Katolik Widya Mandira \\ Jl. Achmad Yani, Kupang, Nusa Tenggara Timur, Indonesia
}

\author{
ARTICLE INFO \\ Received: 2021-01-19 \\ Revised: 2021-03-25 \\ Accepted: 2021-06-17 \\ Keywords: \\ Concept, Mathematics \\ teaching aids, Products, \\ Training
}

\begin{abstract}
Props are aids used to ease students understand well the mathematical concepts explained by the teacher. Elementary school level requires real concepts so that in concretizing abstract concepts the teacher should be able to use props to explain the concept. The purposes of the community service are teachers are able to produce props in learning activities and can instill basic concepts so that they are able to solve commonly faced problems in learning activities. The method used is a practical method. This community service was carried out at SD GMIT Koro'oto, Kupang Regency, East Nusa Tenggara. Based on evaluation result of the community service, it shows that teachers participated actively in the activity shown by their responses and interactions. In addition, the teachers felt the importance of this training because they gained a lot of new knowledge in solving every problem in learning activities and were able to produce props that could help explain basic concepts to students.
\end{abstract}

(C)2021 Published by University of Merdeka Malang. This is an open access article distributed under the CC BY-SA 4.0 license (https://creativecommons.org/licenses/by-sa/4.0/)

How to cite: Djong, K. D., Jagom, Y. O., Leton, S. I., Rowa, Y. R., Uskono, I. V., Dosinaeng, W. B. N., \& Lakapu, M. (2021). Pelatihan Penggunaan Alat Peraga Matematika bagi Guru SD GMIT Koro'oto, Kupang, Nusa Tenggara Timur. Abdimas: Jurnal Pengabdian Masyarakat Universitas Merdeka Malang, 6(3), 427-438. https://doi.org/10.26905/abdimas.v6i3.5334

\section{PENDAHULUAN}

Alat peraga merupakan suatu benda yang dapat digunakan untuk membantu pengajar dalam menerangkan atau menjelaskan materi pembelajaran kepada peserta didik, sehingga peserta didik mampu mempelajari suatu bidang yang akan dipelajari sehingga lebih efektif dan efisien dalam menangkap serta memahami materi ajar yang disampaikan oleh pengajar. Alat peraga dapat mengkongkritkan materi ajar yang sifatnya abstrak menjadi lebih mudah untuk dipahami. Suatu benda yang dapat digunakan dalam kegiatan pembelajaran matematika sering dijadikan sebagai alat peraga untuk dapat menjelaskan materi ajar (Nasaruddin, 2015). Selain itu, alat peraga juga merupakan alat bantu yang dipergunakan untuk menjelaskan materi ajar sehingga informasi yang disampaikan oleh pendidik dapat lebih mudah dipahami oleh peserta didik (Jagom \& Uskono, 2019). Alat peraga dapat diartikan sebagi suatu prangkat 
ABDIMAS: Jurnal Pengabdian Masyarakat Universitas Merdeka Malang Volume 6, No. 3, August 2021: 427-438

berupa benda konkrit yang dirancang sedemikian hingga dapat membantu menanamkan konsepkonsep dasar dalam pembelajaran (Annisah, 2014). Oleh karena itu, dinyatakan alat peraga merupakan suatu bentuk benda kongkrit yang dapat memfasilitasi setiap kegiatan pembelajaran sehingga dapat menyokong peserta didik dalam memahami konsep pelajaran yang disampaikan oleh pengajar. Dengan demikian, guru sebagai pengajar dituntut untuk mampu memfasilitasi setiap pelaksanaan pembelajaran sehingga dapat berjalan dengan baik sesuai dengan tujuan pembelajaran.

Namun, pada kenyataannya sebagian besar para pengajar masih belum memanfaatkan atau menggunakan alat peraga secara efektif dalam setiap kegiatan pembelajaran, terlebih khusus dalam pembelajaran matematika. Para pengajar hanya menerangkan konsep yang ada dalam buku teks tanpa menggali kemampuan peserta didik dalam memahami konsep tersebut. Sehingga tidak jarang peserta didik mengalami kendala atau kesulitan dalam menguasai konsep yang diberikan. Terkadang pengajar hanya memandang secara umum kemampuan dari masing-masing peserta didik, misalnya ada yang secara cepat menangkap materi ajar yang telah disampaikan oleh guru namun ada yang mengalami kesulitan dalam menguasai materi ajar yang disampaikan oleh pengajar.

Masalah yang sering kali ditemui di lapangan atau di sekolah sampai saat ini masih banyak pengajar yang jarang menggunakan alat peraga atau media dalam kegiatan pembelajaran, memuat kurang lebih tujuh alasan pengajar untuk tidak menggunakan media pembelajaran atau alat peraga, yaitu merasa penggunaan media itu repot, media dirasa canggih dan mahal, tidak bisa menggunakan media, media hanya untuk hiburan (membuat siswa main-main dan tidak serius) sedangkan belajar itu serius, tidak tersedia media pembelajaran di sekolah, kebiasaan menikmati ceramah/bicara, dan kurangnya penghargaan dari atasan (Sundayana, 2015). Hal lain mengapa guru jarang menggunakan alat peraga dalam kegiatan pembelajaran dikarenakan waktu untuk menyiapkan pembelajaran sangat terbatas, sulit menemukan alat peraga yang sesuai dengan materi pelajaran serta kurangnya akomodasi dalam menghasilkan alat peraga tersebut (Murdiyanto \& Mahatama, 2014).

Selanjutnya permasalahan yang berhubungan dengan penggunaan alat peraga dalam kegiatan pembelajaran, kenyataannya masih banyak sekolah yang tidak menyediakan alat peraga pembelajaran (Setiahati et al., 2018). Hal ini diakibatkan banyak aspek yang menyebabkannya, diantaranya ungkapan mengajar dengan menggunakan media itu sangat mengganggu dalam beraktivitas, sudah terbiasa mengajar dengan menggunakan metode konvensional, kurang adanya inovasi berkaitan dengan alat peraga pembelajaran, kurangnya kreativitas, serta waktu yang tidak cukup untuk membuat alat peraga pembelajaran matematika sederhana. Sementara, alat peraga dapat dimanfaatkan untuk menjadikan media pembelajaran yang dapat meningkatkan motivasi dan ketertarikan peserta didik pada suatu pokok bahasan tertentu karena peserta didik cenderung akan berpikir ke bentuk kongkrit daripada abstrak. Pemahaman konsep yang baik berimplikasi terhadap konsep-konsep matematis yang dipelajari sebagai satu kesatuan yang tidak terpisahkan (Dosinaeng et al., 2020).

Alternatif lain dalam menghasilkan alat peraga sendiri tidak dapat dilakukan dengan baik dikarenakan pemahaman guru-guru dalam merancang dan membuat alat peraga masih sangat terbatas. Guru belum dibekali secara khusus dalam menghasilkan pemahaman tersebut (Nugraha \& Somatanaya, 2018). Selanjutnya, yang paling dasar dan penting yaitu kedudukan alat peraga terkait dengan fungsi pedagogis yang merupakan salah satu upaya untuk meningkatkan proses interaksi guru dengan 
peserta didik di lingkungan belajarnya (Fadilllah et al., 2019). Oleh karena itu, dengan adanya alat peraga dapat memberikan dampak realitas dalam mengajar sehingga lebih terarah dalam menyampaikan tujuan dari pembelajaran serta membangkitkan minat dan motivasi belajar peserta didik yang dapat ditunjukkan dengan kreativitas yang dimiliki.

Manfaat dari penggunaan alat peraga matematika dalam kegiatan pembelajaran dapat dijabarkan sebagai berikut: (1) Dengan menggunakan alat peraga, peserta didik akan mengikuti kegiatan pembelajaran dengan gembira dan dapat meningkatkan minat, motivasi, serta selalu bersikap baik terhadap pembelajaran matematika; (2) Dengan disampaikannya konsep matematika yang abstrak maka melalui alat peraga dapat mengkonkritkannya menjadi lebih sederhana dan mudah untuk dipahami dan dimengerti; (3) Dengan adanya alat peraga dapat meningkatkan daya visual peserta didik karena tidak hanya membayangkan bentuk-bentuk geometri saja melainkan dengan melalui gambar dan bendabenda kongkrit yang akan membantu daya visual peserta didik sehingga lebih berhasil dalam belajarnya (Murdiyanto \& Mahatama, 2014).

Fungsi alat peraga adalah sebagai berikut: (1) Merupakan sarana dalam menghasilkan aktivitas kegiatan pelaksanaan pembelajaran yang lebih efisien, sebagai sarana dalam mentransformasikan konsep-konsep dasar matematika serta mempercepat aktivitas belajar mengajar di kelas; (2) Peserta didik tidak merasa jenuh atau lelah karena guru sudah menjelaskan dengan menggunakan alat peraga dalam memperagakan materi yang disampaikan sehingga peserta didik tetap fokus; (3) Meningkatkan motivasi serta semangat peserta didik untuk belajar (Rusmawati, 2017). Selain itu, fungsi dari media pembelajaran alat peraga dibagi dalam dua bagian yaitu fungsi bagi pengajar dan fungsi bagi peserta didik. Fungsi bagi pengajar antara lain: (1) Sebagai petunjuk dan arahan dalam mencapai tujuan pembelajaran; (2) Menghasilkan desain pembelajaran secara terstruktur; (3) Menghasilkan kerangka sistematis mengajar secara baik; (4) Melancarkan kendali pengajar terhadap materi pelajaran; (5) Mendukung untuk meningkatkan kecermatan dan ketelitian dalam menyajikan materi pelajaran; (6) Meningkatkan rasa percaya diri bagi pengajar; (7) Meningkatkan mutu dan kualitas dari suatu kegiatan pembelajaran (Sundayana, 2015). Fungsi alat peraga bagi peserta didik antara lain untuk: (1) Membangkitkan semangat dan minat belajar peserta didik; (2) Menghasilkan serta mengkombinasikan cara belajar peserta didik; (3) Membagikan desain materi pelajaran serta memudahkan peserta didik untuk belajar; (4) Menghasilkan inti informasi, pokok-pokok secara terstruktur sehingga mempermudah peserta didik untuk belajar; (5) Merangsang peserta didik untuk berfokus dan beranalisis; (6) Menciptakan kondisi dan situasi belajar tanpa tekanan (Sundayana, 2015).

Adapun alat peraga yang akan digunakan dalam kegiatan pengabdian berupa penurunan rumus luas bangun datar, yang diawali dengan penurunan rumus luas persegi panjang, selanjutnya diperoleh rumus luas bangun datar yang lain yaitu, luas persegi, luas segitiga, luas jajargenjang, luas belahketupat, luas layang-layang, dan luas lingkaran.

Berdasarkan hasil observasi dan diskusi dengan 5 orang guru SD GMIT Koro'oto, diperoleh beberapa informasi sebagai berikut: (1) 75\% guru SD GMIT Koro'oto belum menggunakan alat peraga dalam kegiatan pembelajaran khususnya media pembelajaran atau alat peraga matematika; (2) Belum semua guru SD GMIT Koro'oto diberi kesempatan untuk mengikuti kegiatan pelatihan guna membuat alat. Selain itu sebagian besar guru-guru SD GMIT Koro'oto merupakan guru kelas sehingga besar 
ABDIMAS: Jurnal Pengabdian Masyarakat Universitas Merdeka Malang Volume 6, No. 3, August 2021: 427-438

harapan dari guru-guru SD GMIT Koro'oto untuk mendapatkan informasi-informasi baru berkaitan dengan pengembangan konsep-konsep matematika. Karena jika pendalaman konsep dasar bisa dikuasai dengan baik maka guru-guru mampu menyelesaikan setiap persoalan yang dihadapi dalam kegiatan pembelajaran.

Pemahaman konsep matematis merupakan dasar dari setiap tujuan materi yang disampaikan oleh guru, sebab guru merupakan pembimbing siswa untuk mencapai konsep yang diharapkan (Yulianty, 2019). Selanjutnya pemahaman konsep matematis merupakan dasar bagi guru dalam mempermudah siswa untuk mempelajari matematika serta menerapkannya dalam kehidupan sehari-hari (Febriyanto et al., 2018). Pemahaman konsep matematika merupakan salah satu kecakapan atau kemahiran dalam matematika yang diharapkan tercapai dalam belajar matematika dengan menunjukkan pemahaman konsep matematika yang dipelajarinya, serta mampu menjelaskan keterkaitan antara konsep yang satu dengan yang lainnya dan dapat diaplikasikan secara luwes, akurat, efisien, dan tepat dalam pemecahan masalah (Handayani, 2016). Oleh karena itu, pemahaman konsep matematika perlu dikembangkan dengan baik dalam menyelesaikan setiap pemecahan masalah.

Berangkat dari uraian permasalahan yang dijabarkan tersebut maka tim mengadakan "Pelatihan Penggunaan Alat Peraga Matematika dan Pendalaman Konsep Bagi Guru-Guru SD GMIT Koro'oto, Desa Nekamese, Kecamatan Amarasi, Kabupaten Kupang, Nusa Tengara Timur (NTT)". Kegiatan pengabdian ini bertujuan: (1) Agar guru-guru SD GMIT Koro'oto mampu menggunakan alat peraga dalam kegiatan pembelajaran serta memberikan tambahan bagi peserta tentang cara pembuatan alat peraga matematika; (2) Mampu menguasai konsep-konsep dasar dalam menyelesaikan masalah yang sering dihadapi dalam kegiatan pembelajaran; serta (3) Untuk mengetahui respon guru-guru terhadap kegiatan pengabdian yang dilakukan.

\section{METODE}

Metode yang dilakukan dalam kegiatan pelatihan penggunaan alat peraga dan pendalaman konsep matematika bagi guru-guru SD GMIT Koro'oto yaitu diskusi, penyuluhan, dan pendampingan. Lokasi kegiatan dilaksanakan di SD GMIT Kooro'oto. Jl. H.R. Koroh. Desa Nekamese, Kecamatan Amarasi Selatan, kabupaten Kupang, NTT (gambar 1). Pelaksanaan kegiatan pada tanggal 09 September 2020. Jumlah guru yang mengikuti kegiatan tersebut 24 orang. Gambar 1 menunjukkan peta lokasi kegiatan pengabdian.

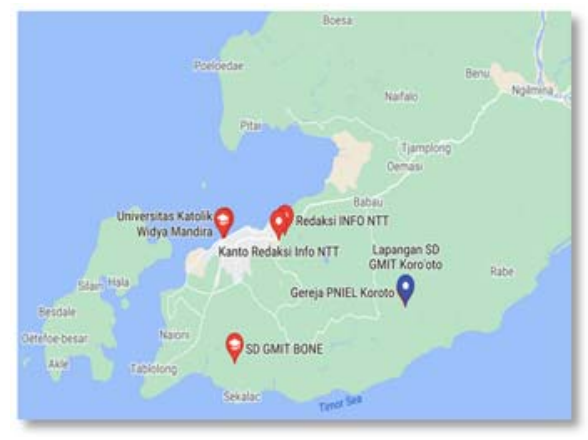

Gambar 1. Peta lokasi kegiatan pengabdian 
Adapun alat peraga yang digunakan dalam kegiatan pengabdian ini diantaranya mencari luas persegi panjang, mencari luas persegi, mencari luas segitiga, mencari luas jajargenjang, mencari luas belah ketupat, mencari luas layang-layang, mencari luas trapesium, dan mencari luas lingkaran. Konsep dasar yang dikembangkan yaitu turunan dari luas persegi panjang. Turunan persegi panjang dapat mengaitkan turunan rumus bangun datar lainnya.

Tahapan-tahapan pelaksanaan kegiatan yang dilakun sebagai berikut: (1) Persiapan yang terdiri dari: (a) Penentuan tempat pelaksanaan pengabdian; (b) Mengenali setiap permasalahan yang dihadapi oleh subjek pengabdian; (c) Mencatatajenis-jeinis alat peraga yang dibutuhkan; dan (d) Mengenali sarana dan prasarana serta sumber belajar yang terdapat di lokasi pengabdian; (2) Pelaksanaan yang terdiri dari: (a) Melakukan pemaparan materi berkaitan dengan pembuatan alat peraga serta penggunaannya; (b) Melakukan kegiatan pengabdian sesuai dengan rancangan yang telah dibuat; dan (c) Menghasilkan rancangan beberapa alat peraga yang dapat digunakan dalam kegiatan pembelajaran; (d) Melakukan praktik cara menggunakan alat peraga yang dibuat dalam pembelajaran matematika; (3) Implementasi yang terdiri dari: (a) Pendampingan cara pembuatan alat peraga bagi guru-guru; dan (b) Membuat bahan ajar yang dapat digunakan berkaitan dengan penggunaan alat peraga dalam pembelajaran matematika; (4) Peran mitra dalam pelaksanaan kegiatan adalah menyediakan tempat untuk dapat terlaksananya kegiatan pelatihan tersebut dan mempersiapkan guru-guru untuk dapat mengikuti kegiatan pelatihan tersebut; (5) Evaluasi pelaksanaan kegiatan dengan cara: (a) Memberikan angket kepada peserta untuk mengetahui respon dari setiap pelaksanaan pengabdian yang telah dilakukan; (b) Menginformasikan kepada peserta untuk mampu mengahasilkan alat sesuai dengan materi pembelajaran; dan (c) Melakukan refleksi terhadap hasil kegiatan yang telah dilakukan.

\section{HASIL DAN PEMBAHASAN}

Pengabdian ini dilaksanakan di SD GMIT Koro'oto. Sekolah ini berlokasi di Jl. H.R. Koroh, Desa Nekamese, Kecamatan Amarasi Selatan, Kabupaten Kupang, Nusa Tenggara Timur. Hasil yang dicapai dalam kegiatan pengabdian pada masyarakat ini terdiri atas perencanaan, pelaksanaan kegiatan, implementasi, peran mitra, dan evaluasi pelaksanaan.

\section{Persiapan}

Tahap perencana dilaksanakan pada bulan Juni tahun 2020 yang melibatkan kepala sekolah serta guru-guru terkait rencana dan rancangan kegiatan yang dilakukan sebagai berikut: (1) Analisis kebutuhan yaitu dengan melakukan analisis kegiatan pembelajaran matematika, serta menganalisis keterampilan guru untuk menggunakan alat peraga dalam kegiatan pembelajaran; (2) Malakukan analisis jenis-jenis alat peraga yang sering digunakan dalam kegiatan pembelajaran di kelas; (3) Persiapan yang diperlukan dalam pelkasanaan kegiatan seperi alat dan bahan dalam membuat alat peraga matematika. 
ABDIMAS: Jurnal Pengabdian Masyarakat Universitas Merdeka Malang Volume 6, No. 3, August 2021: 427-438

\section{Pelaksanaan kegiatan dan implementasi}

Kegiatan pelatihan pembuatan alat peraga matematika bagi guru-guru SD dilaksanakan pada bulan September tahun 2020, bertempat di SD GMIT Koro'oto, Kabupaten Kupang, Nusa Tenggara Timur (NTT). Kegiatan ini dibagi dalam tiga rangkaian kegiatan. Waktu kegiatan dimulai dari pukul 08.00 WITA sampai pukul 15.00 WITA yang dihadiri oleh 24 peserta dari dua sekolah. Kegiatan ini diawali dengan pendalaman materi berkaitan dengan konsep-konsep dasar matematika, kemudian dilanjutkan dengan bimbingan dalam menghasilkan alat peraga matematika, serta yang terakhir dilakukan evaluasi terhadap pelaksanaan kegiatan pengabdian yang telah dilaksanakan. Teknis pembuatan alat peraga yang dilakukan antara lain tim pengabdian menyiapkan alat dan bahan berupa karton, penggaris, cutter, dan pensil. Selanjutnya tim pengabdian dan para guru membuat serta mempraktikan hasil alat peraga yang telah dibuat. Berikut merupakan gambaran pelaksanaan kegiatan yang telah dilakukan oleh tim pengabdian dalam melaksanakan kegiatan serta beberapa hasil alat peraga yang telah dibuat.
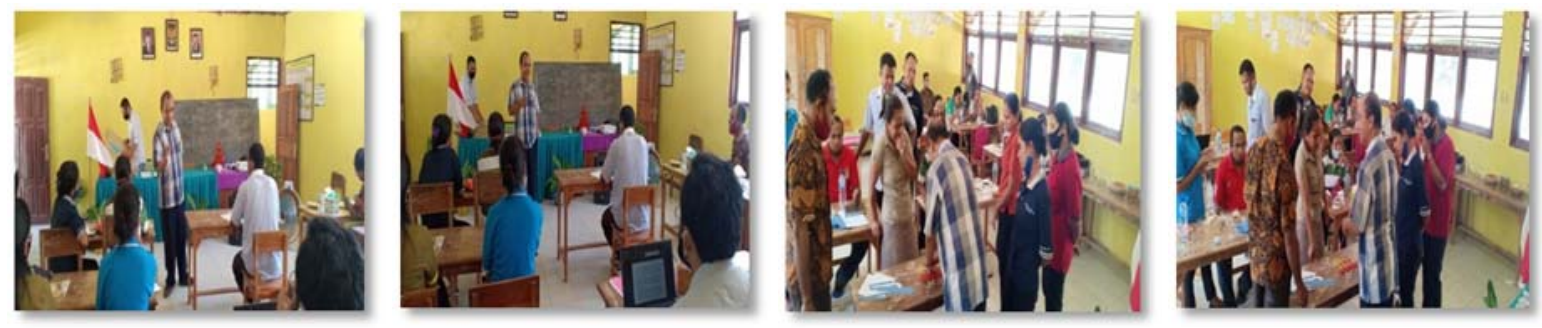

Gambar 2. Penanaman konsep bagi guru SD

Gambar 3. Penggunaan alat peraga dalam pembelajaran
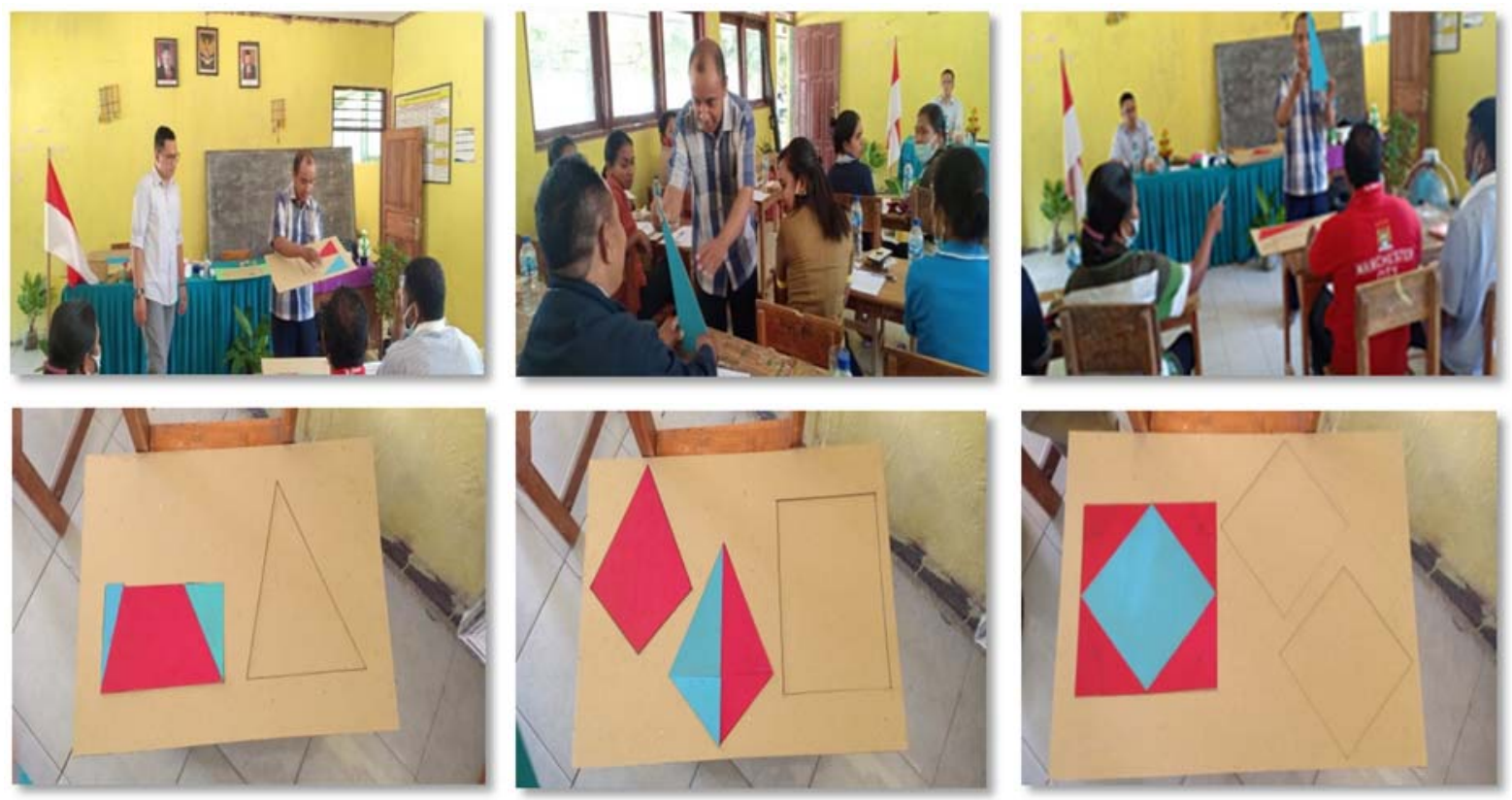

Gambar 4. Simulasi penggunaan alat peraga dalam pembelajaran

Gambar 5. Beberapa alat peraga yang dihasilkan 
Berdasarkan Gambar 2 terlihat ketua tim pengabdian memberikan penjelasan kepada guru berkaitan dengan konsep-konsep dasar dalam pembelajaran matematika serta mengungkapkan permasalahan-permasalahan yang seringkali dijumpai dalam kegiatan pembelajaran di kelas. Selanjutnya pada Gambar 3 dan Gambar 4 tim pengabdian bersama guru-guru melakukan simulasi berkaitan dengan penggunaan alat peraga matematika yang dapat digunakan dalam kegiatan pembelajaran di kelas. Gambar 5 merupakan contoh alat peraga yang dihasilkan dalam kegiatan pengabdian. Alat peraga tersebut antaralain segitiga, layang-layang, dan belah ketupat. Penurunan rumus dari bangun tersebut menggunakan pendekatan rumus luas persegi panjang.

\section{Peran mitra dalam pelaksanaan kegiatan}

Mitra yang terlibat langsung dalam kegiatan pengabdian ini merupakan guru-guru SD GMIT Koro'oto. Keterlibatan mitra dalam kegiatan sebagai peserta sehingga dapat mengkoordinasi setiap kebutuhan-kebutuhan yang digunakan dalam pelaksanaan kegiatan pengabdian ini. Berikut merupakan foto kegiatan yang dilakukan oleh mitra dalam pelaksanaan kegiatan. Kegiatan dibuka oleh kepala sekolah sebagai pimpinan di sekolah mitra dalam sambutannya kepala sekolah menyampaikan pentingnya kegiatan ini sehingga menjadi dasar bagi mitra dalam membangun kerjasama selanjunya dalam meningkatkan mutu pendidikan secara khusus di SD GMIT Koro'oto.
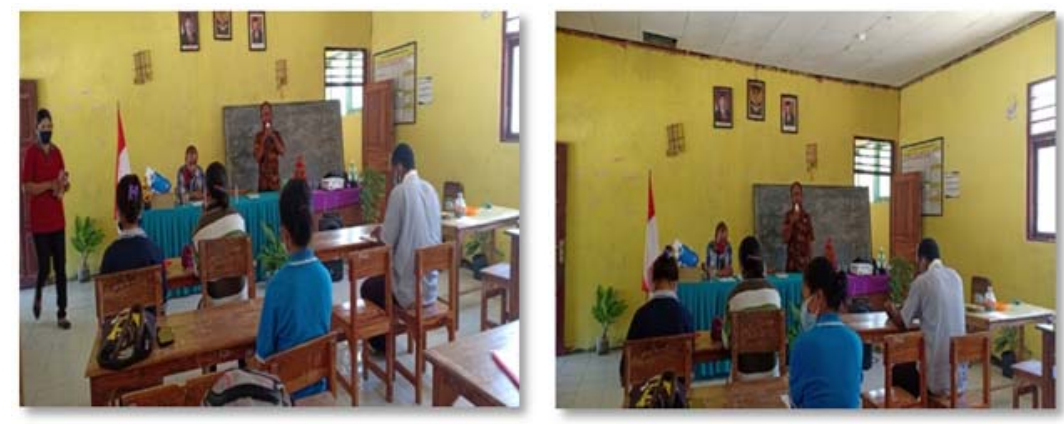

Gambar 6. Penjelasan mitra yang dilakukan Kepala Sekolah Dasar GMIT Koro'oto

\section{Evaluasi kegiatan}

Evaluasi kegiatan bertujuan untuk mengetahui keberhasilan dari kegiatan yang dilakukan. Evaluasi dilakukan setelah kegiatan pelatihan dilaksanakan dengan membagikan kuesioner kepada peserta pelatihan guna dilakukan analisis terhadap tanggapan yang telah diberikan oleh peserta. Berikut merupakan jawaban dari peserta berkaitan dengan kegiatan yang dilakukan yang ditampilkan dalam bentuk Tabel 1. 
ABDIMAS: Jurnal Pengabdian Masyarakat Universitas Merdeka Malang Volume 6, No. 3, August 2021: 427-438

Tabel 1. Hasil jawaban kuesioner kegiatan pelatihan

\begin{tabular}{|c|c|c|}
\hline No & Indikator & Total Jawaban \\
\hline $1 a$ & Sangat Paham & 14 \\
\hline $1 b$ & Paham & 8 \\
\hline $1 c$ & Kurang Paham & 2 \\
\hline $1 d$ & Tidak Paham & 0 \\
\hline $2 a$ & Sangat Bermanfaat & 14 \\
\hline $2 b$ & Bermanfaat & 10 \\
\hline $2 c$ & Kurang Bermanfaat & 0 \\
\hline $2 d$ & Tidak Bermanfaat & 0 \\
\hline $3 a$ & Sangat Membantu & 20 \\
\hline $3 b$ & Membantu & 4 \\
\hline $3 c$ & Kurang membantu & 0 \\
\hline $3 d$ & Tidak Membantu & 0 \\
\hline $4 a$ & Sangat Membantu & 16 \\
\hline $4 b$ & Membantu & 8 \\
\hline $4 c$ & Kurang membantu & 0 \\
\hline $4 d$ & Tidak Membantu & 0 \\
\hline $5 a$ & Sangat Lancar & 19 \\
\hline $5 b$ & Lancar & 5 \\
\hline $5 c$ & Kurang Lancar & 0 \\
\hline $5 d$ & Tidak Lancar & 0 \\
\hline
\end{tabular}
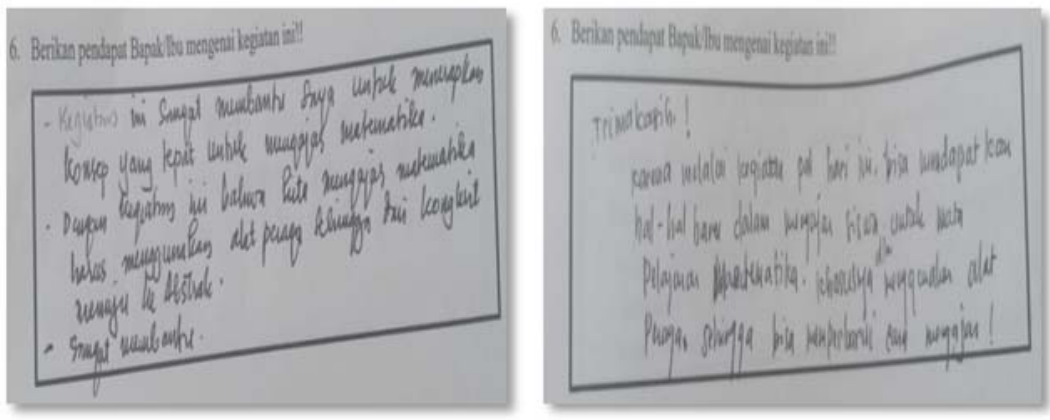

Gambar 6. Respon peserta kegiatan

Berdasarkan pelaksanaan kegiatan serta dilakukan evaluasi akhir untuk mengetahui tingkat keberhasilan dari kegiatan pelatihan pembuatan alat peraga matematika secara keseluruhan terlihat dari jawaban soal nomor 1 terkait pemahaman konsep terhadap materi yang diajarkan, 58,34\% responden dari 24 responden menjawab sangat paham, kemudian $33.33 \%$ responden menjawab paham serta 
8,33\% responden menjawab kurang paham. Dengan demikian, berdasarkan hasil presentasi jawaban responden lebih dominan sangat paham terhadap materi yang disampaikan.

Soal nomor 2 terkait manfaat kegiatan pelatihan yaitu 58,34\% responden dari 24 responden menjawab sangat bermanfaat dan $41,66 \%$ responden menjawab bermanfaat. Dengan demikian, berdasarkan hasil presentasi jawaban responden lebih dominan sangat bermanfaat terhadap pelatihan yang telah dilakasanakan. Soal nomor 3 terkait dengan membantu meningkatkan profesionalisme guru yaitu $83,34 \%$ responden dari 24 responden menjawab sangat membantu dan 16,66\% responden menjawab membantu. Dengan demikian, berdasarkan hasil presentasi jawaban responden lebih dominan sangat membantu dalam meningkatkan profesionalisme guru.

Soal nomor 4 terkait dengan mengatasi kesulitan yang dialami guru dalam kegiatan pembelajaran yaitu 66,67\% responden dari 24 responden menjawab sangat membantu dan 33,33\% responden menjawab membantu. Dengan demikian, berdasarkan hasil presentasi jawaban responden lebih dominan sangat membantu dalam mengatasi kesulitan yang dialami guru dalam kegiatan pembelajaran. Soal nomor 5 terkait dengan kelancaran kegiatan yaitu 79,16\% responden dari 24 responden menjawab sangat lancar dan 20,83\% responden menjawab lancar. Dengan demikian, berdasarkan hasil presentasi jawaban responden lebih dominan sangat lancar dalam melaksanakan kegiatan pelatihan. Adapun pendapat yang disampaikan oleh responden dalam kegiatan ini sebegian besar mengatakan paham dan sangat membantu bagi guru-guru dalam mengatasi masalah yang selamai ini sering dihadapi serta dapat membuka wawasan baru bagi guru-guru dalam memberikan solusi bagi peserta didik.

Selanjutnya dapat memberikan penyegaran dalam membangkitkan pemahaman dari guru-guru berkaitan dengan pemahaman konsep matematika yang dapat membangkitkan semangat bagi peserta didik dalam memahami proses penyelesaian masalah. Ungkapan lain juga mengakatan bahwa pelatihan ini selain mendapatkan pengetahuan yang baru tetapi bagaiman cara mengajar yang baik supaya peserta didik mengerti dengan apa yang telah disampaikan. Selain itu, keaktifan dari masing-masing peserta dalam keterlibatan pengabdian ini sangat tinggi yang ditunjukkan dengan begitu banyak pertanyaan-pertanyaan serta keingintahuan dari masing-masing sehingga kegiatan yang dilaksanakan dapat berjalan sesuai dengan target yang diinginkan oleh tim pengabdian. Sehingga para guru mampu mengetahui prosedur pembuatan alat peraga yang baik serta mampu mengaplikasikannya dalam pelaksanaan kegiatan pembelajaran.

\section{Pembahasan}

Kegiatan pengabdian ini bertujuan untuk para pengajar mampu menerapkan dan mengaplikasikan alat peraga dalam kegiatan pembelajaran serta mampu menguasai konsep-konsep dasar dalam menyelesaikan masalah yang sering dihadapi serta untuk mengetahui respon guru-guru terhadap kegiatan pengabdian yang dilaksanakan.

Berdasarkan hasil evaluasi pelaksanaan pengabdian yang telah diuraikan diatas menghasilkan pengaruh positif yang sangat besar bagi para guru-guru SD GMIT Koro'oto. Para guru sangat memahami setiap pemberian materi yang disampaikan berdasarkan respon yang diberikan secara keseluruhan guru 
ABDIMAS: Jurnal Pengabdian Masyarakat Universitas Merdeka Malang Volume 6, No. 3, August 2021: 427-438

mampu berpartisipasi aktif dan membagi pengalaman yang dialami selama melaksanakan kegiatan pembelajaran di kelas. Kegiataan pelatihan ini sangat bermanfaat dalam membantu dan meningkatkan profesionalisme guru, sehingga guru mampu mengembangkan kemampuan diri dalam menyusun perangkat pembelajaran dengan menggunakan media-media yang sesuai agar mampu menghasilkan tujuan pembelajaran yang diinginkan. Selain itu guru juga dapat melakukan kerjasama dengan teman sejawat dalam satu tim untuk meningkatkan kemampuan profesionalisme guru melalui pemberian masukan, saran, nasehat, atau bantuan teman sejawat. Kegiatan pelatihan ini dapat mengatasi setiap kesulitan yang dialami oleh guru dalam pelaksanaan pembelajaran di kelas, sehingga dapat menawarkan solusi terbaik untuk menyelesaikan persoalan tersebut.

Selain itu pelatihan penggunaan alat peraga ini juga merupakan hal yang sangat dibutuhkan oleh guru-guru SD GMIT Koro'oto. Seperti yang diungkapkan oleh Kepala Sekolah dasar GMIT Koro'oto kegiatan seperti ini sangat bermanfaat bagi mereka dan sekiranya memungkinkan mereka ditahuntahun akan datang pengabdian sejenis dapat lagi dilaksanakan. Karena banyak hal yang diperoleh dari pelaksanaan kegiatan ini. Misalnya dapat meningkatkan motivasi bagi guru-guru untuk menghasilkan media sederhana dalam membangkitkan semangat dan kreativitas dari peserta didik. Selain itu, guruguru juga mendapatkan informasi baru berkaitan dengan perkembangan ilmu pengetahuan yang semakin berkembang sehingga perlu adanya referensi-referensi baru dalam memperbaharui pola mengajar yang dilakukan. Hal ini sejalan dengan hasil pengabdian yang dijelaskan oleh Azmi et al. (2019), guru-guru mampu menggunakan alat peraga yang tepat dalam kegiatan pembelajaran matematika sehingga dapat mengkongkritkan benda-benda yang abstrak menjadi lebih sederhana, serta dapat meningkatkan daya tarik siswa dalam kegiatan pembelajaran matematika agar menjadi lebih aktif dan menyenangkan. Dilanjutkan dengan yang diungkapkan Subarinah et al. (2020), Pembuatan alat peraga dapat meningkatkan keterampilan guru sehingga dapat meningkatkan kualitas pembelajaran di kelas.

Dengan demikian, pelaksanaan kegiatan pelatihan ini merupakan bentuk sosialisasi yang dapat meningkatkan kreativitas guru-guru dalam menggunakan alat peraga sehingga mampu menyelesaikan setiap persoalan yang ditemukan dalam kegiatan pembelajaran. Selain itu, dapat meningkatkan pengetahuan guru tentang alat peraga matematika, pengetahuan tentang cara menghasilkan alat peraga matematika, pengetahuan tentang cara memakai alat peraga matematika, serta gambaran konsep dasar dalam menyelesaikan persoalan matematika, dan gambaran praktik pembelajaran matematika berbantuan alat peraga matematika.

\section{SIMPULAN DAN SARAN}

Berdasarkan hasil dan pembahasan dapat disimpulkan bahwa pelaksanaan kegiatan pengabdian penggunaan alat peraga matematika serta pendalaman konsep matematika bagi guru-guru SD GMIT Koro'oto dapat meningkatkan: (1) Pengetahuan tentang alat peraga matematika; (2) Pengetahuan tentang cara menghasilkan alat peraga matematika; (3) Pengetahuan tentang cara memakai alat peraga matematika; (4) Pengetahuan konsep dasar dalam menyelesaikan persoalan matematika; dan (5) gambaran praktik pembelajaran matematika berbantuan alat peraga matematika. 
Perlu adanya sosialisasi serta pelatihan alat peraga bagi guru-guru SD untuk terus memperbaharui setiap perkembangan ilmu pengetahuan yang terbaru dalam dunia pendidikan sehingga mampu mengatasi setiap permasalahan pembelajaran. Serta perlu adanya pendampingan dalam pembutan alat peraga matematika yang interaktif dalam meningkatkan minat dan motivasi belajar dari peserta didik.

\section{UCAPAN TERIMA KASIH}

Tim pengabdian menyampaikan terima kasih kepada LPPM Universitas Katolik Widya Mandira yang telah mendanai kegiatan pengabdian ini sehingga kegiatan pengandian ini dapat berjalan sesuai dengan target yang diharapkan.

\section{DAFTAR PUSTAKA}

Annisah, S. (2014). Alat peraga pembelajaran matematika. Tarbawiyah: Jurnal Ilmiah Pendidikan, 11(1), $1-15$.

Azmi, S., Sripatmi, S., Subarinah, S., Amrullah, A., \& Turmuzi, M. (2019). Pelatihan pembuatan alat peraga pembelajaran matematika untuk meningkatkan profesionalisme guru-guru Gugus II AMPENAN Utara. Jurnal Pendidikan dan Pengabdian Masyarakat, 2(4), 427-432.

Dosinaeng, W. B. N., Djong, K. D., Leton, S. I., Lakapu, M., Jagom, Y. O., \& Uskono, I. V. (2020). Pendalaman konsep geometri dan pembuatan media pembelajaran bagi guru-guru SD Kota Soe. DINAMISIA: Jurnal Pengabdian Kepada Masyarakat, 4(4), 619-627. https://doi.org/10.31849/dinamisia.v4i4.4084

Fadilllah, S., Wahyudi, W., \& Nurhayati, N. (2019). Pelatihan pembuatan dan penggunaan alat peraga matematika dan IPA bagi guru SD dan SMP di Desa Tanjung Saleh. Jurnal Pengabdian Masyarakat MIPA dan Pendidikan MIPA, 3(1), 43-47. https://doi.org/10.21831/jpmmp.v3i1.21460

Febriyanto, B., Haryanti, Y. D., \& Komalasari, O. (2018). Peningkatan pemahaman konsep matematis melalui penggunaan media kantong bergambar pada materi perkalian bilangan di kelas II sekolah dasar. Jurnal Cakrawala Pendas, 4(2), 32-44.

Handayani S. D. (2016). Pengaruh konsep diri dan kecemasan siswa terhadap pemahaman konsep matematika. Formatif: Jurnal Ilmiah Pendidikan MIPA, 6(1), 23-34.

http://dx.doi.org/10.30998/formatif.v6i1.749

Jagom, Y. O., \& Uskono, I. V. (2019). Pengaruh penggunaan alat peraga berbahan bekas terhadap hasil belajar matematika siswa SMP. Math Didactic: Jurnal Pendidikan Matematika, 5(3), 219226. https://doi.org/10.33654/math.v5i3.613

Murdiyanto, T., \& Mahatama, Y. (2014). Pengembangan alat peraga matematika untuk meningkatkan minat dan motivasi belajar matematika siswa sekolah dasar. Sarwahita, 11(1), 38-43.

Nasaruddin, N. (2015). Media dan alat peraga dalam pembelajaran matematika. Al-Khwarizmi: Jurnal Pendidikan Matematika dan Ilmu Pengetahuan Alam, 3(2), 21-30.

https://doi.org/10.24256/jpmipa.v3i2.232

Nugraha, D. A., \& Somatanaya, A. G. (2018). Pelatihan perancangan dan aplikasi alat peraga matematika sekolah dasar. Jurnal Pangabdian Siliwangi, 4(2), 186-191. 
ABDIMAS: Jurnal Pengabdian Masyarakat Universitas Merdeka Malang Volume 6, No. 3, August 2021: 427-438

Rusmawati, R. (2017). Penggunaan alat peraga langsung pada pembelajaran matematika dengan materi pecahan sederhana untuk meningkatkan hasil belajar siswa. Suara Guru: Jurnal Pendidikan Sosial, Sains dan Humaniora, 3(2), 307-314. http://dx.doi.org/10.24014/suara\%20guru.v3i2.3607

Setiahati, I. P., Lisnani, L., \& Triayomi, R. (2018). Pelatihan pembuatan alat peraga pembelajaran matematika sederhana di SD Negeri 42 Palembang. Jurnal Abdimas Musi Charitas, 2(2), 13-16.

Subarinah, S., Hayati, L., Amrullah, Prayitno, S., \& Junaidi. (2020). Pelatihan pembuatan dan penggunaan alat peraga matematika untuk membelajarkan konsep dan operasi bilangan bulat bagi guruguru SD di Gugus IV Cakranegara. Jurnal PEPADU: Lembaga Penelitian dan Pengabdian Kepada Masyarakat, 1(2), 191-197.

Sundayana, R. H. (2015). Media dan Alat Peraga Dalam Pembelajaran Matematika. Bandung: Alfabeta.

Yulianty, N. (2019). Kemampuan pemahaman konsep matematika siswa dengan pendekatan pembelajaran matematika realistik. Reflesia: Jurnal Pendidikan Matematika, 4(1), 60-65. https://doi.org/10.33449/jpmr.v4i1.7530 